\title{
JUURNAL.RU
}

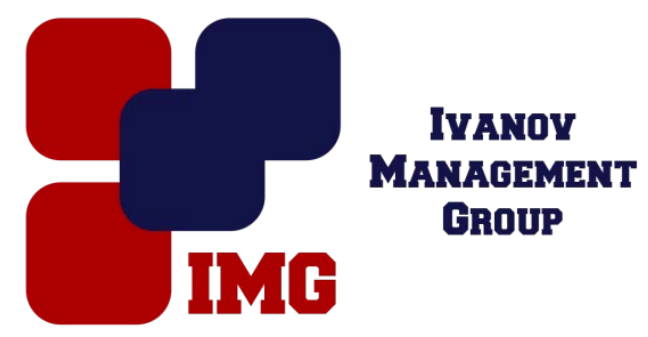

Осипова Е. О., Храмова А. А., Пичхидзе С.Я. СГТУ им. Ю.А.Гагарина

Саратов, Россия

doi: 10.18411/lj-31-10-2016-3-09

idsp 000001:lj-31-10-2016-3-09

\section{Разработка мембраны диализатора}

Искусственная почка - это аппарат, предназначенный для выведения из крови человека токсинов, скапливающихся в почках при их тяжелом поражении - обычно это хроническая и острая формы недостаточности почек. Работа аппарата основывается на принципах диализа - это выведение низкомолекулярных веществ из коллоидных растворов благодаря диффузии и разнице между осмотическим давлением с двух сторон полупроницаемой мембраны [1..4]. Диализатор - устройство, в котором полупроницаемая мембрана отделяет очищаемую кровь пациента от очищающего раствора. Площадь мембраны диализатора должна составлять 1-2 м2 - это необходимо для того, чтобы стандартный диализ проходил достаточно эффективно. В современных диализаторах мембрана представлена капиллярными волокнами диаметром примерно 200 мкм, внутри которых протекает кровь, а снаружи капилляры омывает диализирующий раствор. В результате мембраны «упакованы» в компактный цилиндр $30 * 5$ см [2]. Обычно в качестве диализной мембраны используют пленки из полимерных материалов различной природы (целлофан, поливинилхлорид, полиамид, ацетат целлюлозы). Недостатком этих мембран является то, что они синтетические, в основном это - полимеры углеводов и их производных, в то время как биологические мембраны состоят из липидов и белков. Метод применения подобных диализных мембран носит название метода изолированных органов. Указанные мембраны наиболее близки к предлагаемым и выбраны за прототип. Несмотря на естественную природу 
используемых биологических мембран, они имеют недостатки в использовании: а) для выделения подобных мембран требуется производить забой животных, б) выделенные мембраны имеют очень маленькую рабочую поверхность, в) мембраны из-за содержащихся в них липидов и белков быстро подвергаются процессам окисления [3].

Цель работы: усовершенствование мембраны диализатора аппарата искусственная почка. К апробации нами предлагается мембрана, рис.2, состоящая из двухслойного синтетического нетканого материала ПАН-ПВДФ, полученная методом электроформования, на которую с помощью клея в виде фторопластовой дисперсии Ф-4Д наносится два внешних каркасных слоя, изготовленных из перфорированного полипропилена для придания прочности мембране. Полученная мембрана позволяет отфильтровывать мочевину, а также такие простые органические соединения, как креатинин, фенол-дериваты, проникающие через поры мембраны. Также данная мембрана способствует отсутствию абсорбции антикоагулянтов и медикаментов.

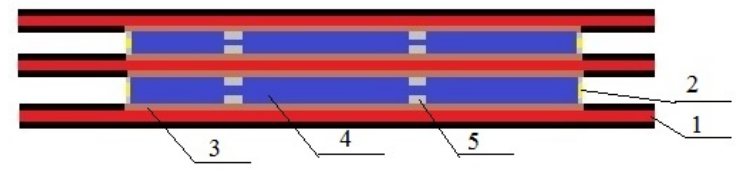

Рис.1. Принцип очищения крови, где: 1-кровь, 2соединяющий слой, 3-мембрана, 4-фильтрат, 5кремниевый микрочип

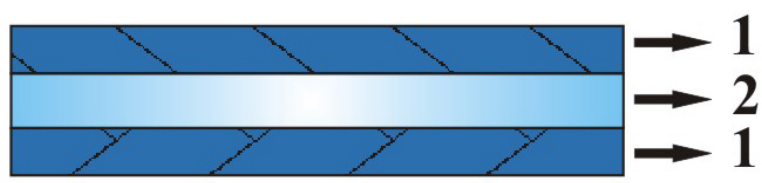

Рис.2. Мембрана, где: 1 - каркасный слой, 2 нетканый материал

Выводы: предложена мембрана для очистки водных биологических жидкостей, изготовленная из синтетического нетканого материала ПАН-ПВДФ методом электроформования. 


\section{Литература}

1. http://tvoelechenie.ru/urologiya/chto-takoe-iskusstvennaya-pochka-pri-kakixorganizuetsya-procedura.html

2. Земченков А.Ю., Герасимчук Р.П., Костылева Т.Г., Виноградова Л.Ю., Земченкова И.Г., Сучков В.Н., Вишневский К.А. - Жизнь с хронической болезнью почек: Беседы с пациентом. - СПб., 2013. - 174 с.

3. Патент РФ № 2202835 С1. Способ получения моделей биологических мембран/ Кайшева Н.Ш., Москаленко С.В., 20.04.2003.

4. Калюжный А.О., Пичхидзе С.Я. Усовершенствование конструкции имплантата почки. Курск: ЮЗГУ, 2016.-3с. 